\title{
Quality Assurance Program Description for Shipping Packages of Radioactive Materials
}

Prepared for the

U.S. Nuclear Regulatory Commission

Pacific Northwest Laboratory

Richland, Washington 99352

Operated for the

U.S. Department of Energy

by

\section{Baftelle}

Memorial Institute 


\title{
NOTICE
}

This report was prepared as an account of work sponsored by the United States Covernment. Neither the United States nor the United States Nuclear Regulatory Commission, nor any of their empioyees, nor any of their contractors, subcontractors, or their employees, makes any warranty, express or implied, or assumes any lezai liability or responsibility for the accuracy, completeness or usefulness of any information, apparatus, product or process disclosed, or represents that its use would not infringe privately owned rights.

\author{
PACIFIC NORTHWEST LABORATORY \\ operated by \\ BATTELLE \\ for the \\ UNITED STATES DEPARTMENT OF ENERGY \\ Under Contract EY-76-C-06-1830
}

Printed in the United States of America Available from

National Technical Information Service United States Department of Commerce

5285 Port Royal Road

Springfield, Virginia 22151

Price: Printed Copy $\$$ *; Microfiche $\$ 3.00$

NTIS

- Pages Se!ling Price

$001-025 \quad \$ 4.50$

026-050 $\$ 5.00$

$051-075 \quad \$ 5.50$

076-100 \$E.00

$107-125 \quad \$ 6.50$

$126-150 \quad \$ 7.00$

$151-175 \quad \$ 7.75$

$17 t_{1}-200 \quad \$ 8.50$

$20 \%-225 \quad \$ 8.75$

$226-250 \quad \$ 9.00$

$25 \div-275 \quad \$ 10.00$

$276-300 \quad \$ 10.23$ 
PNL-2686

\section{2}

\section{QUALITY ASSURANCE PROGRAM DESCRIPTION FOR} SHIPPING PACKAGES OF RADIOACTIVE MATERIAL

Prepared for the

U.S. Nuclear Regulatory Commission

Pacific Northwest Laboratory

Richland, Washington 99352 
.

m

...

-

.

. 


\section{RECORD OF REVISIONS}

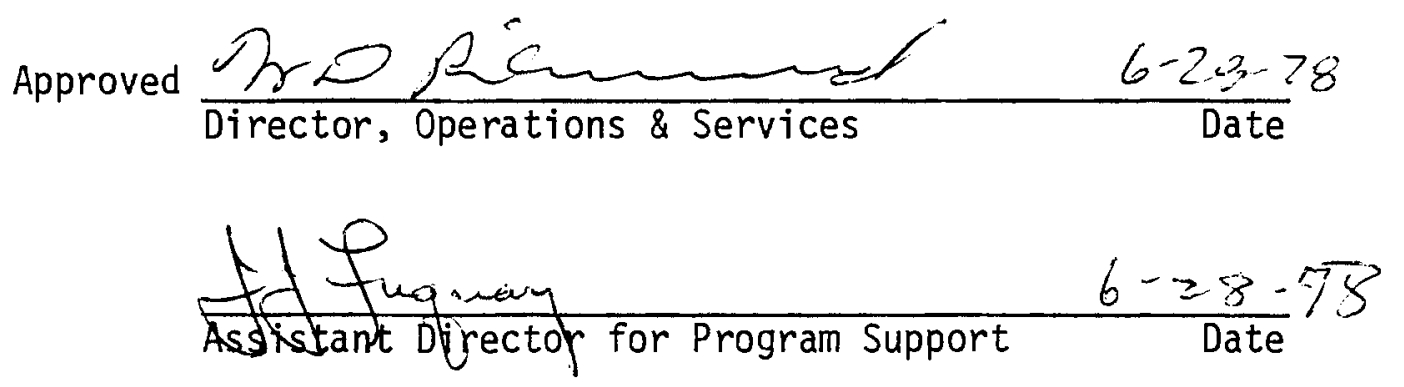

Manua 1

Revision No.

0
Purpose For

Revision

Initial issue
Date

$\underline{\text { Released }}$ 
This quality assurance plan describes the quality assurance program at the Pacific Northwest Laboratory (PNL), for shipping packages of radioactive material. The purpose of this report is to describe how PNL will comply with the Code of Federal Regulations, Title 10, Part 71, Appendix E.

In compliance with the instructions from the Nuclear Regulatory Commission (NRC), the 18 criteria from Appendix E are covered. 
IABLE OF CONTENTS

\begin{tabular}{|c|c|c|c|}
\hline \multicolumn{2}{|l|}{ Item } & $\begin{array}{l}\text { Revision } \\
\text { Status } \\
\end{array}$ & Page No. \\
\hline \multicolumn{2}{|c|}{ Cover Page } & 0 & $i$ \\
\hline \multicolumn{2}{|c|}{ Record of Revisions } & 0 & $i i$ \\
\hline \multicolumn{2}{|c|}{ Summary } & 0 & $i i i$ \\
\hline \multicolumn{2}{|c|}{ Table of Contents } & 0 & iv \\
\hline \multicolumn{2}{|c|}{ Introduction } & 0 & 1 \\
\hline I & Organization & 0 & 2 \\
\hline II & Quality Assurance Programs & 0 & 3 \\
\hline I I I & Design Control & 0 & 4 \\
\hline IV & Procurement Document Control & 0 & 5 \\
\hline v & Instructions, Procedures and Drawings & 0 & 5 \\
\hline VI & Document Control & 0 & 6 \\
\hline VII & $\begin{array}{l}\text { Control of Purchased Material, Equipment } \\
\text { and Services }\end{array}$ & 0 & 6 \\
\hline VIII & $\begin{array}{l}\text { Identification and Control of Material } \\
\text { Parts and Components }\end{array}$ & 0 & 7 \\
\hline IX & Control of Special Processes & 0 & 7 \\
\hline$x$ & Inspection & 0 & 8 \\
\hline$X I$ & Test Control & 0 & 8 \\
\hline$X I I$ & Control of Measuring and Test Equipment & 0 & 9 \\
\hline XII I & Handling, Storage and Shipping & 0 & 9 \\
\hline XIV & Inspection Test and Operating Status & 0 & 9 \\
\hline$x V$ & Nonconforming Material, Parts or components & 0 & 10 \\
\hline$X V I$ & Corrective Action & 0 & 10 \\
\hline XVII & Quality Assurance Records & 0 & 11 \\
\hline XVIII & Audits & 0 & 11 \\
\hline Appen & & 0 & $A-1$ \\
\hline
\end{tabular}


,

$-$$$
-
$$

...

-

.

$-$

$\cdots$

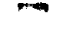

$\ldots$ 
QUALITY ASSURANCE PROGRAM DESCRIPTION FOR

SHIPPING PACKAGES OF RADIOACTIVE MATERIAL

\section{INTRODUCTION}

The Pacific Northwest Laboratory (PNL) which is operated by Battelle Memorial Institute, will make radioactive material shipments in compliance with Code of Federal Regulations, Title 10 (10 CFR), Part 71.

The quality assurance program that is summarized in the following sections is provided by the Manager, Quality Assurance Office, who reports to the Assistant Director for Program Support. This QA program description covers shipments of radioactive material that do not include high-level waste, irradiated fuel, or plutonium in excess of the amounts listed in Part 150 of 10 CFR. 
The Pacific Northwest Laboratory (PNL) has a Quality Assurance Office that is responsible for developing the quality assurance program for PNL, assisting in its implementation, and auditing for compliance. An organization chart (Figure 1) shows the relationship of the Quality Assurance Office with other PNL components.

The Transportation Safety Officer, who is associated with the Safety and Nuclear Materials Management Section, is responsible for the training and qualification, document control, inspection, and auditing activities associated with controlling radioactive material shipments. He has the authority to stop any shipment of radioactive material that does not meet regulations. He works with the Quality Assurance Office to maintain the documents relating to purchasing specification containers, inspection, and test results. He also coordinates with representatives from the Radiation Standards and Engineering Section concerning audits.

\section{QUALITY ASSURANCE PROGRAMS}

The PNL quality assurance program is administered by the Manager, Quality Assurance Office, and the overall quality assurance program for shipment of radioactive materials is documented in company management guides and manuals (see Appendix). These guides and manuals provide the procedures by which training, controls and surveillance, inspection, tests, and reviews are accomplished. These guides and manuals emphasize controlling the package characteristics that are critical to safety. 
The Transportation Safety Officer assures that all radioactive material shipping packages are designed and manufactured under a quality assurance program consistent with the above guides and manuals and approved by the Nuclear Regulatory Commission (NRC) for a 11 packages designed or fabricated after July 1, 1978. The method for assuring that regulations are complied with is discussed in the following sections.

\section{I DESIGN CONTROL}

Design and/or fabrication of new containers shall not be undertaken by PNL. Any design or fabrication of new containers shall be subcontracted. It shall be the responsibility of PNL to determine that the subcontractor can manufacture the desired packages in compliance with the appropriate regulations and safety criteria. After a subcontractor has been selected, PNL's responsibilities will include:

- reviewing and approving design, drawings, purchase specifications and fabrication procedures,

- reviewing, approving and releasing any design changes,

- making certain that the subcontractors understand they are responsible for preparation and implementation of a documented quality control plan,

- assuring that the prime subcontractor passes appropriate QA requirements to their subcontractors or supplier to furnish a documented quality control plan for safety related equipment and components, 
- establishing and applying independent design, safety audit, and review procedures,

- auditing subcontractors' quality control performance for compliance with approved plans and attainment of safety objectives,

- defining the type and extent of acceptance tests and auditing the acceptance testing for compliance with approved procedures, and

- evaluating test data.

IV PROCUREMENT DOCUMENT CONTROL

Procurement activities shall be planned and performed in accordance with the PNL procurement and quality assurance manuals (see Appendix). These manuals provide assurance that quality requirements are suitably defined in the documentation concerned with procurement of equipment, materials and services. The manuals also require that suppliers provide appropriate quality control plans to demonstrate attainment of requisite quality. In addition, the Transporation Safety Officer will review these procurement documents.

$V \quad$ INSTRUCTIONS, PROCEDURES AND DRAWINGS

Written instructions, procedures, drawings or other types of documents sha11 be used to control activities that have a significant impact on quality. Management personnel, the Transportation Safety Officer, and the quality assurance representative sha11 identify those project or service 
activities affecting quality that require written instructions, procedures or drawings. The identified instructions and procedures shall include, as appropriate, the following, in sufficient detail to adequately control the affected activity:

- prerequisite conditions

- applicable codes, standards, and specifications

- performance sequence and methods

- personnel, equipment and procedure qualification requirements

- acceptance criteria.

VI DOCUMENT CONTROL

Management shall ensure that controlled documents are prepared, reviewed and approved for use. In addition, management shall ensure that the documents are distributed and used at the location where the prescribed activity is performed. Changes in released documents shall be subject to the same controls as those applied to the original documents. The same organizations that performed the original review and approval shall review and approve all changes.

The Transportation Safety Officer shall ensure that all radioactive material shipments are conducted in accordance with the latest applicable changes to these controlled documents.

VII CONTROL OF PURCHASED MATERIAL, EQUIPMENT AND SERVICES

By means of documented procedures, manuals, supporting inspections, and audits, provisions will be made to assure that items procured by PNL or 
by a sub-contractor meet established quality requirements. These provisions include, as appropriate, the following:

- source evaluation by qualified personnel

- review of material certifications

- review of specification compliance reports

- review of test results and inspection reports

- inspection at the subcontractors' facilities and of products upon delivery.

Reporting of deficient material identification and disposition procedures will also be provided.

VIII IDENTIFICATION AND CONTROL OF MATERIALS, PARTS, AND COMPONENTS

Quality asurance plans and other procedures will include provisions for assuring that quality-sensitive materials, parts, and components are identified from acquisition through final application. This identification will be used, as required, to prevent use of incorrect, defective, or uncontrolled items.

IX CONTROL OF SPECIAL PROCESSES

Any special processes that concern new containers will be carried out by a qualified contractor that has established procedures to assure requisite quality. Through appropriate contract provisions, PNL will make certain that the subcontractor provides appropriate documentation of materials certification, and qualification records of procedures and personnel. 
INSPECTION

Inspection requirements for in-process and final inspection activities affecting the quality of critical items will be outlined in procurement documentation. Specification of the type of inspection will be based on the particular conditions, e.g., material control and in-process monitoring in which non-destructive testing of finished items cannot provide complete demonstration of quality. Use will be made of mandatory hold points where required, to assure compliance with design and specifications. Inspections performed by PNL will follow established procedures, and will involve persons other than those who performed the activity being inspected.

\section{TEST CONTROL}

The Pacific Northwest Laboratory shall require appropriate test control from any subcontractor that has been contracted to fabricate a container. Subcontractors will be approved, in part, on the basis of the adequacy of their test programs. It will be required that test requirements and acceptance limits be defined in documented procedures. These documented procedures will contain provisions for assuring that tests are properly performed and that test results are documented and evaluated to verify attainment of required quality.

The Transporation Safety Officer will ensure that PNL personnel perform tests following written procedures and using proper equipment under proper conditions. Test results will be evaluated by qualified personnel. 
XII CONTROL OF MEASURING AND TEST EQUIPMENT

Measuring and test equipment used by PNL personnel on package components shall be calibrated to standards traceable to nationally recognized standards, or when no such standards exist, the method for calibration wi 11 be documented. The Quality Assurance Manual defines calibration levels and describes controls applicable to measuring and test equipment used at PNL.

When measuring and test equipment are used by a subcontractor, PNL will require, as appropriate, documented results of the test performed and certification that the measurements were made with calibrated instruments.

\section{HANDLING, STORAGE AND SHIPPING}

Written procedures for handiing, storage and shipping radioactive materials will be followed. Shipments will not be made until it has been determined that the container: 1) has a current certificate of compliance; 2) has been inspected and released; 3) has been packaged according to written procedures; and, 4) has packaging records completed for future filing.

The radioactive material shipping representative from each department will perform the critical handling, storage and shipping operations. Before the shipment is released, the Transportation Safety Officer shall make final inspection of the packaging. The Transportation Safety Officer shall sign a certification indicating that the shipment meets all applicable regulations.

\section{INSPECTION, TEST, AND OPERATING STATUS}

Inspection, test, and operating status of packages will be indicated and controlled by written procedures. Status will be indicated by a tag; no 
package wi11 be used unless an accept tag has been attached. The Transportation Safety Officer shall ensure that the container is approved for use and that the status indicators are properly applied.

XV NONCONFORMING MATERIAL, PARTS OR COMPONENTS

Procedures will be followed that ensure the identification, control, and disposition of nonconforming items. These procedures will include appropriate measures to prevent inadvertent use or installation of material, parts or components that do not conform to approved drawings or specifications. Disposition requirements include documented procedures for review of nonconforming items for acceptance, rejection, rework, or repair, and for ultimate disposition.

\section{CORRECTIVE ACTION}

By contractural agreement and where appropriate, PNL will hold subcontractors responsible for corrective action. When a subcontractor is commissioned to fabricate a container, he will be required to identify conditions adverse to quality, investigate the cause of the condition, and document the corrective action taken. The subcontractor will be responsible for followup action to ensure that the corrective action has been taken.

If PNL performs corrective action, a corrective action request procedure, outlined in the Quality Assurance Manual, will be followed. 


\section{QUALITY ASSURANCE RECORDS}

Records of package approval, procurement, inspections, tests, audit results, personnel training and qualifications, and shipments will be maintained. These records will be identifiable and retrievable. An index of the records, indicating storage location, will be maintained by the Quality Assurance Office and the Transportation Safety Office.

\section{AUDITS}

Periodic and scheduled audits shall be performed to verify the program's effectiveness. The audits shall be performed by the Quality Assurance Office and other organizations that have no responsibility in the activity being audited.

The audits will be performed using written checklists, and the findings and appropriate corrective action will be documented. Copies of the audit report will be provided to the responsible managers. Audit personnel will perform followup action to ensure that designated corrective action has been adequately performed. 

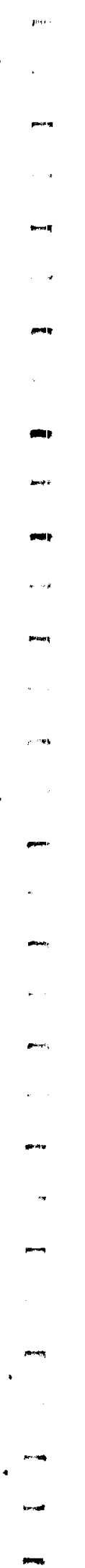


\section{APPENDIX}

Guides and Manuals

\section{Management Guides}

MG 5.4 Quality Assurance

MG 12.12 Packaging and Transportation of Radioactive Material

MG 5.9 Records Management

MG 9.6 Engineering Drawings

MG 8.1 Procurement

Manua 1s

PNL-MA-65 Quality Assurance Manua 1

BNWL-MA-81 Radioactive Materials Shipping Manual

BNWL-MA-6 Radiation Protection Procedures

PNL-MA-5 Nuclear Materials Management Procedures

BNWL-MA-67 A User:'s Guide to Procurement

DATE ISSUED:

$6 / 30 / 78$
PNL- 2686

SECTIONS APPENDIX

PAGE 1 OF 1 

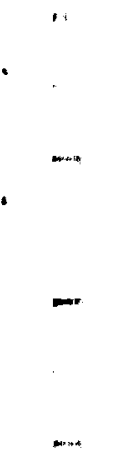

$\infty$

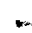

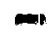

$\cdots$

-

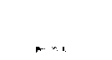

.........

$m$

-
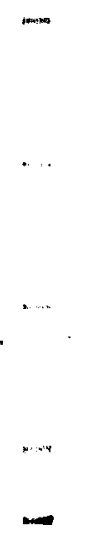

mins 


\section{DISTRIBUTION}

No. of

Copies

OFFSITE

6 C. E. McDonald, Chief Transportation Branch Nuclear Regulatory Commission Division of Fuel Cycle and Material Safety Washington, DC 20555

27 DOE Technical Information Center
No. of

Copies

ONSITE

1 DOE Richland Operations Office

H. E. Ransom

15 Pacific Northwest Laboratories

L. A. Carter

J. J. Fuquay

H. L. Henry

H. V. Larson

W. D. Richmond

J. E. Ruffin

D. E. Ryder

R. E. Shippert

J. M. Taylor

Technical Information (5)

Technical Publications 
